\title{
INTERMEDIARIES BOOSTING THE DIGITAL TRANSFORMATION OF SMES: A COMPARATIVE ANALYSIS BETWEEN ITALY AND THE RUSSIAN FEDERATION
}

\author{
Dominique PhD Candidate and Assistant Lecturer, Department of Political Science, \\ Lepore Communication and International Relations, University of Macerata; \\ Address: Via Giovanni Mario Crescimbeni, 30/32, MC, Italy, 62100. \\ E-mail: d.lepore@studenti.unimc.it
}

Fabio PhD Candidate and Assistant Lecturer, Department of Political Science, CommunicaCoacci tion and International Relations, University of Macerata (IT); Address: Via Giovanni Mario Crescimbeni, 30/32, MC, Italy, 62100;

PhD Candidate and Lecturer, Department of World Political Processes, School of Governance and Politics, Moscow State Institute of International Relations (RU); Address: 76, Prospekt Vernadskogo, Moscow, Russian Federation, 119454.

E-mail: f.coacci1@studenti.unimc.it

\begin{abstract}
The article aims at investigating the role of entrepreneurial associations as intermediaries in supporting the digital transformation of small and medium-enterprises in Italy and the Russian Federation. The state-of-theart is analyzed taking into account the level of digitalization of SMEs in both countries and the activities and features of the most relevant entrepreneurial associations in their role as intermediaries between private businesses and public rulers.

The article adopts a comparative method based on the Italian and Russian experience: Confindustria and Confartigianato in Italy are considered in comparison to Opora in the Russian Federation. The findings of the research show high expectations on the role of entrepreneurial intermediaries in supporting the digital transformation of SMEs. Accordingly, directions for the further development of their role are drawn.
\end{abstract}

Keyword: SMEs, Italy, Russian Federation, Industry 4.0, Digitalization, Entrepreneurial Associations, Digital Innovation Hubs, Opora Russia.

\section{Introduction}

Small and medium-sized enterprises (SMEs) are recognized as the cornerstones of the economic growth of many economies ${ }^{1}$. Nevertheless, in the Russian Federation SMEs play a weak role in the economy, contrary to most OECD countries, especially Italy.

The Fourth Industrial Revolution with the adoption of advanced and connected technologies ${ }^{2}$, could be an opportunity for boosting the development of SMEs in the Russian Federation.

However, it should be taken into account that SMEs are facing difficulties in embracing this digital transformation (DX) ${ }^{3}$. To overcome such challenges, intermediary actors connecting SMEs to external stakeholders (ie. academia, firms, institutions) could enable their DX [1]. It is crucial to facilitate access to know-how and new technologies that are more easily accessible to large enterprises. Russian SMEs could become properly competitive only by providing them with those assets and technologies which are essential in the current global market and the lack of which can jeopardize their survival.

\footnotetext{
${ }^{1}$ OECD. Enhancing the contributions of SMEs in a global and digitalised economy. Paris: OECD Publishing, 2020.

${ }^{2}$ Kagermann H., Wahlster W., Helbig. J. Recommendations for implementing the strategic initiative INDUSTRIE 4.0, Final report of the Industrie 4.0. Frankfurt am Main: Working Group Acatech, 2013.

${ }^{3}$ OECD. SME and Entrepreneurship. Outlook 2019. Policy Highlights. Paris: OECD Publishing, 2020.
} 
Aware of the outlined context, a comparative analysis is provided on intermediary actors in Italy, where the share of SMEs is relevant, and the Russian Federation, which is dominated by large companies. To this aim, we consider through desk research the role of Confindustria and Confartigianato in Italy in comparison to OPORA RUSSIA in the Russian Federation.

The article is structured as follows. First, the call for intermediary actors for supporting the DX of SMEs is reviewed. Second, a comparative analysis between Italy and the Russian Federation is provided, considering the role of entrepreneurial associations. Lastly, policy implications and future avenues of research are drawn.

\section{The digital transformation of SMEs: call for intermediary actors}

The adoption of advanced digital technologies is the core of the fourth industrial revolution, referred to as Industry 4.0 (I4.0). The concept of I.4.0, introduced in the early 2010s, describes the increasing integration of automation and digitalization in the manufacturing processes ${ }^{1}$. I4.0 is based on a complex system of interrelated technologies [2], including Advanced Cyber Physical-Systems (CPS), Industrial Internet of Things (IoT), big data and cloud computing [3].

There are several opportunities in embracing the DX, especially for SMEs. For instance, DX promotes the emergence of "born global" small firms, which can serve customers internationally. SMEs can use digital technologies to better understand the processes within the firm and the overall business environment. They can take advantage of these technologies to improve their access to skills and talent, which in turn can help improve performance.

However, SMEs are facing difficulties in adopting these concepts due to their limited financial and organizational resources². Therefore, efforts are required for introducing SMEs to I4.0 [4].

To unlock the potential of technological advancements, collaborative strategies may be beneficial for SMEs, as a means to exchange knowledge. Above all, collaboration is the core enabler of I.4.0 [5].

This adoption of advanced technologies, such as I4.0, could be facilitated by intermediary actors supporting SMEs' digital transformation by connecting key stakeholders, as regional and national institutions, firms, academia and users [1].

\section{Italian SMEs and digital transformation}

The role played by Italian SMEs ${ }^{3}$ in the non-financial sector is larger than the average of the EU with a value-added of $67.1 \%$ against the EU average of $56.8 \%$ and $78.5 \%$ of employment against the EU average of $66.4 \%{ }^{4}$. Digital technologies make SMEs of Made in Italy more competitive, enabling them to develop new distribution channels and ways to create and deliver value to customer segments [6].

However, according to the Ministry of Economic Development's investigation conducted on a sample of firms, only $6 \%$ of micro-enterprises are using I4.0 technology, against 18,4\% of small enterprises, 35,5\% of medium enterprises and $47,1 \%$ of large ones ${ }^{5}$.

To support the adoption of I4.0 technologies the National Plan Industry 4.0 "Piano Nazionale Industria 4.0" known today as "Piano Impresa 4.0" was introduced for boosting investments and innovation for the period 2017 - 2020. The plan focuses on enabling:

\footnotetext{
${ }^{1}$ Kagermann H., Wahlster W., Helbig. J. Recommendations for implementing the strategic initiative INDUSTRIE 4.0, Final report of the Industrie 4.0. Working Group Acatech, Frankfurt am Main, 2013.

${ }^{2}$ OECD. SME and Entrepreneurship. Outlook 2019. Policy Highlights. Paris: OECD Publishing, 2020.

${ }^{3}$ The main classes used are micro enterprises: with less than 10 persons employed; small enterprises: with 10-49 persons employed; medium-sized enterprises: with 50-249 persons employed; small and medium-sized enterprises (SMEs): with 1-249 persons employed; large enterprises: with 250 or more persons employed Commission Recommendation of 6 May 2003 concerning the definition of micro, small and medium-sized enterprises [notified under document number C(2003) 1422], Official Journal of the European Union, L 124/36.

${ }^{4}$ European Commission. SBA. Fact Sheet. Italy, 2018.

${ }^{5}$ MISE-MET. La Diffusione delle Imprese 4.0 e le Politiche. Evidenze 2017. 2018.

${ }^{6}$ Piano Nazionale Industria 4.0. URL: https://www.mise.gov.it/images/stories/documenti/Piano_Industria_40.pdf
} 
- innovative investments - incentivize private investment in the adoption of Industry 4.0 technologies and increase the expenditure for research and development;

- enabling infrastructures - ensure appropriate network infrastructures, safety and protection of data and collaborate in defining standards of interoperability at the international level;

- competences and research - create competences and incentivize research with specific training;

- awareness and e-Governance - spread knowledge on the potential applications of Industry 4.0 technologies and ensure public-private governance.

Several measures have been adopted such as: a) incentives for investing in new material and immaterial, capital goods for integrating digital technologies in production processes; b) partial subsidies to cover the interest paid for loans granted from banking institutes c) measures addressed to facilitate the access to credit by recognizing the possibility of achieving grants without additional guarantees; d) tax credits recognized for incremental expenses in R\&D; e) tax breaks from income resulting from the usage of immaterial goods as industrial patents, registered brands, industrial models, know-how and software with copyright; f) tax credit for training expenses of employees linked to I4.0 technologies listed in the Plan.

Some of the measures include specific ones for SMEs as the case of the tax credit for training, where the budget bill of 2019 has recognized to small enterprises a voucher-grant for consultancy between 2019 and 2020.

Among these measures, particularly relevant is the development of a network of Digital Innovation Hubs (DIHs) for supporting the DX and introduction of I4.0 among SMEs. This role as the following paragraph will explain is covered mainly by entrepreneurial associations.

\section{The role of Italian Digital Innovation Hubs}

Italian SMEs can benefit from the support of artisan and industrial associations. This is the case of Confartigianato - representing artisans and micro and small enterprises and the confederation - and Confindustria - addressing enterprises of all sizes.

Confartigianato supports Italian small enterprises in every phase: from the development of the business plan, management of administrative tasks to the introduction of technologies and market positioning. In addition, artisans, self-employed professionals, and small businesses can refer to Confartigianato not only to gain information but also for representing their interests with government agencies and their counterparts in negotiations ${ }^{1}$.

On the other hand, Confindustria provides support for firms of all sizes, and more specifically SMEs through the programme "Piccola Industria" to contribute to the development of SMEs in line with the economic and social directions of the country ${ }^{2}$.

Both Confartigianato and Confindustria enable the adoption of digital technologies for SMEs by participating in the emerging collaborative networks of DIHs. DIHs are an instrument introduced in 2016 by the European Commission to support in a collaborative perspective the DX of SMEs.

DIHs enable firms to become competitive by adopting digital technologies in the products, services and processes. They act as a first regional point of contact, and strengthen the innovation ecosystem by connecting firms, in particular SMEs, to external sources, as universities, research centers, businesses, and institutions. ${ }^{3}$

The Italian context is characterized by a relevant role of industrial and artisan associations, recognized as DIHs. These structures are recognized for the high knowledge they hold on the needs of regional SMEs, which allows them to select the right activities for their DX [2].

\footnotetext{
${ }^{1}$ Confartigianato. https://www.confartigianato.it/inglese/

${ }^{2}$ Confindustria. Piccola Impresa, https://www.confindustria.it/home/piccola-industria

${ }^{3}$ Smart Specialization Platform. Digital Innovation Hubs, https://s3platform.jrc.ec.europa.eu/digital-innovation-hubs.
} 


\section{Russian SMEs and digital transformation}

Even though both preeminent scholars and public rulers recognize Russian SMEs ${ }^{1}$ as one of the key elements for the sustainable and equitable economic development of Russia ${ }^{2}$, SMEs in the Russian Federation lag behind the OCSE average both in terms of number and performance. In fact, the share of SME accounting for GDP is estimated at $20-25 \%$ and less than $30 \%$ of the Russian workforce is employed by these firms. Those data are significantly lower than the other OCSE countries ${ }^{3}$. Moreover, in most Russian regions the trend of business demography is negative since the number of SMEs which fail exceeds the number of created new businesses [7, p. 2]. Accordingly, the share of SMEs, which represents $3.86 \%$ of the total of enterprises, has dropped by $9.2 \%$ over the timeframe 2016-2019. This result may be due to the weak effect of acceleration programmes and measures aimed at improving the business climate.

Considering the DX, Russian firms view digital technologies as a means of communication rather than a source for improving their business productivity and their transactions. The lack of connectivity, digital skills, and digital technology among businesses is significant. The economic incentives driving the digital economy in the EU countries, such as high labor costs and competition, are insufficient in the Russian context [8]. As underlined by Komkov [9] for guaranteeing a competitive and stimulating business climate, it is necessary to incentivize Russian firms in adopting innovative solutions and competitive technologies.

In the last decades, the Russian federation has tried to focus on the development of SMEs carrying out multiple policies to foster their competitiveness and implementing state programs aimed at strengthening their competences, access to financing and innovation. However the impact of these support measures on SMEs has been modest [7, p. 2].

The main measure introduced by the Russian Federation related to the DX of SMEs is represented by the programme Digital Economy of the Russian Federation, which was officially presented at the Creating the Future Leader of the Digital Economy panel discussion in occasion of the Open Innovations forum of October $2018^{4}$.

In the inauguration ceremony of the event, the former Deputy Chair of the Government of the Russian Federation, Maxim Akimov, outlined the main points of the two sets of strategic tasks for the development of the digital economy. The first set deals with the structure of the Russian digital economy by developing a nation-wide data architecture to meet the demands of both businesses and the state and, accordingly, to ensure an efficient and effective implementation of the national SME support measures. The second set of tasks deals with the digital identity i.e. full digitalization for the residency of organizations, things, individuals worldwide, management of solutions and digital profiles of a person, to set up a joint trusted environment. However, rather than focusing on the specific introduction of I4.0 technologies in SMEs and the digitalization of their production activity, the programme mainly deals with the digitalization of the services which the public administration provides to the SMEs and their data.

It is clear that among the main factors of competitiveness fostering the development of Russian SMEs in today's business environment there is the ability to undertake the DX by introducing I4.0 technologies and implementing entrepreneurial behavior and corporate entrepreneurship [10].

Accordingly, the objective of raising economic growth rates requires an institutional reform of SMEs, of which the Digital economy can be considered a starting point, and the adoption of a cohesive and comprehensive development strategy for I4.0 whose target-oriented planning and effective implementation can be driven by a public-private partnership and transnational initiatives of collaboration [11].

\footnotetext{
${ }^{1}$ The definition of SMEs in the Russian Federation differs from the EU definition, that is the reason international comparisons ought to take into account these differences. The current Russian law has established the main criterion for classifying SMEs. This criterion is based on the number of employees engaged in SMEs. The number of employees for micro-enterprises should not exceed 15 people. This figure ranges from 16 to 100 people for small enterprises and from 101 to 250 people for medium enterprises. Federal Law No. 209-FZ dated 24 July 2007 'About Development of Small and Medium Entrepreneurship in the Russian Federation'. URL: https://cis-legislation.com/document.fwx?rgn=17873

${ }^{2}$ European Investment Bank. Small and Medium Entrepreneurship in Russia. EIB: Luxembourg, 2013. URL: https://www.eib.org/attachments/efs/econ_study_small_and_medium_entrepreneurship_in_russia_en.pdf ${ }^{3}$ OECD. Financing SMEs and Entrepreneurs 2020: An OECD Scoreboard. Paris: OECD Publishing, 2020.

${ }^{4}$ Analytical center for the government of the Russian Federation. The Digital Economy national program was officially presented at the Open Innovations forum. 2018. URL: https://ac.gov.ru/en/news/page/the-digital-economy-nationalprogram-was-officially-presented-at-the-open-innovations-forum-18558
} 


\section{The platform for Russian SMEs}

The most important Russian business organization for Russian SMEs is "OPORA RUSSIA", which is a nongovernmental association consisting of about 400,000 entrepreneurs and other individuals from more than 143 industry unions, associations and guilds. The association has branches in 83 regions of Russia.

This association supports Russian entrepreneurs in their business practices in several fields, such as legal protection, financing, governmental support, networking within the business community even at the international level and development of the entrepreneurial activity.

Moreover, OPORA RUSSIA ensures connections between entrepreneurship and political representatives by working as a platform for an effective professional dialogue between owners and managers of SMEs and the federal executive bodies, regional authorities and municipalities, supervisory bodies and experts.

The 15th jubilee of this organization, which took place in VDNK in 2018 and was attended by the President of the Russian Federation Vladimir Putin, can be seen as a practical example of the above-mentioned dialogue. Furthermore, this event represented a valid point of reference to understand the issues faced by SMEs and the proposal forwarded by OPORA to overcome them.

The main issues addressed by OPORA as well as by relevant government ministries are related to the lack of a "single" digital window ensuring state support and the absence of an investment "elevator" for SMEs. Further issues are the insufficient accountability of customers when they violate payment terms, onerous currency controls, the high number of inspections (1.7 million in 2017) and entrepreneurs convicted for infractions, the increase of reporting requirements, underdevelopment of venture financing, inability to submit to banks documents in electronic form, undervalued collateral, and high reserve requirements for lending (75\% in the Russian Federation vs. $50 \%$ or less elsewhere).

In response, Mr Vladimir Putin emphasized his commitment to meet and expand the opportunities for SMEs throughout the country.

In the wake of the former prime minister's argumentation during the 2014 SPIEF, one of the priorities he stressed is to increase government purchases from SMEs as opposed to using historically traditional sources of supply. In his speech, he underlines the need to expand the access of products from small companies to the domestic market and the results already achieved also thanks to the combination of the national effort with the purposeful and productive work of OPORA for the development of SMEs.

Specifically, he pointed out the purchasing growth of SMEs products and services from public companies stating that in 2015 companies with state participation bought goods and services from SMEs for an amount less than one hundred billion rubles a year, and, in 2018, this was already more than three trillion rubles. Furthermore, he highlights the endeavour of the Russian Federation to bring the volume of purchases to the achievable result of five trillion rubles by 2024 .

To meet the above-mentioned requests raised by the entrepreneurs he announced a three-year moratorium on scheduled inspections for most types of state control over small enterprises, which would have ended in December 2020, and he proposed giving entrepreneurs the right to complete and fill out the register of business inspections along with the inspectors themselves. To conclude, he speaks about the adoption of a mechanism to increase the transparency of inspections and laws on social entrepreneurship, which had been already discussed in a previous meeting with NGOs.

As for the relations between OPORA RUSSIA and foreign businesses, the organization is committed to being a point of reference for them by representing an excellent contact and professional advisor for those foreign SMEs who are interested in expanding their activity into the Russian market ${ }^{1}$.

Also, this organization carries out studies and researches on SMEs' activities and provides useful data and figures. In this regard, the dynamic index RSBI (Russian Small Business Index) ${ }^{2}$ is one of the most relevant and accurate indexes about the performance of SMEs. RSBI evaluates business sentiment in three sectors: trade, production, and services. An index value above 50 points means an increase in business activity, below 50 - a decrease. An index of 50 points indicates stagnation in the market. The trend of RSBI, as reported in figure 1, shows an overall stagnation of the SMEs activity for the period $2014-2019$. As for the year 2019, the first semester provided optimistic data showing an improvement of the SMEs' activity, which, however, seems to be resized by a decrease of RSBI for the second and third semesters.

\footnotetext{
${ }^{1}$ See Goncharoff P. SME's have finally gotten Russian attention. Russia Knowledge, 2018. URL:

http://www.russiaknowledge.com/2018/10/30/smes-have-finally-gotten-russias-attention/

${ }^{2}$ Opora Russia. RSBI Opora Index Small and Medium-sized Businesses. 2019.
} 
Figure 1 - RSBI for the period 2014 - 2019

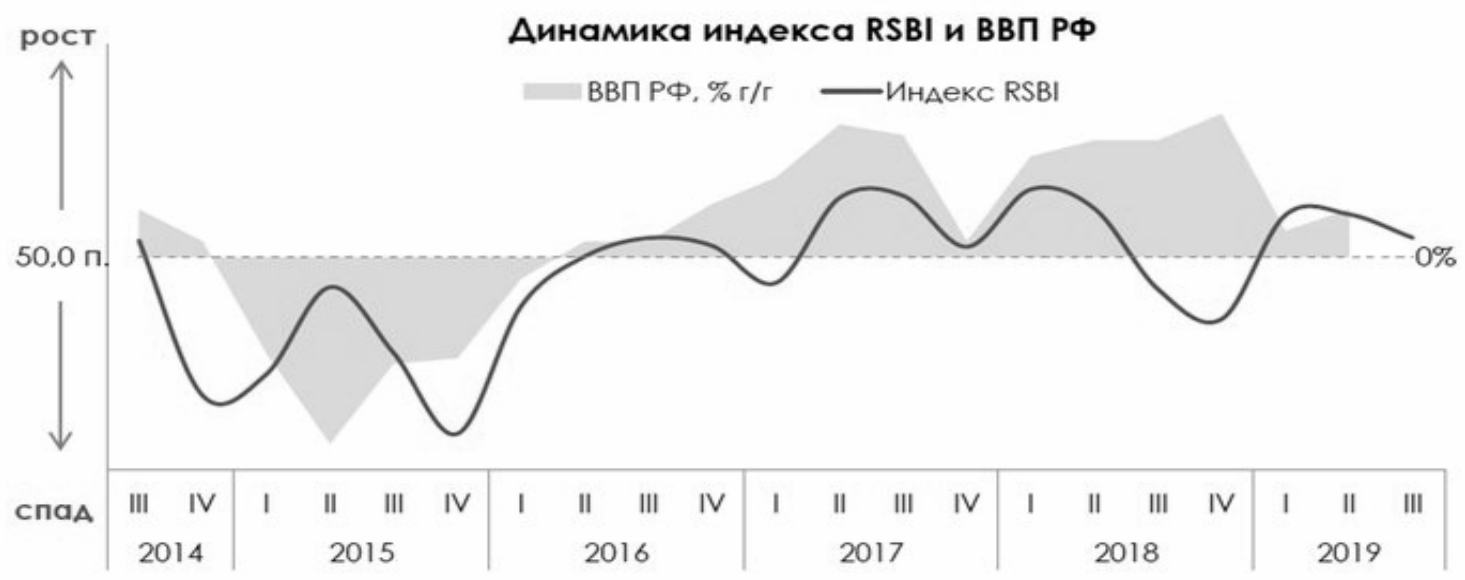

Source: Opora Russia, 2019

Considering the Russian experience, where SMEs have still a low impact on the economy and support measures are excessively fragmented, it may be beneficial to strengthen the role of the OPORA RUSSIA as a reference point for the development of Russian SMEs. OPORA RUSSIA could adopt the collaborative approaches held by the mentioned DIHs, nationally and internationally, to support SMEs become first of all aware of the benefits of digital technologies since as stated by Andrey Turchak, Deputy Speaker of the Federation Council of the Federal Assembly of the Russian Federation: "We know that the state provides a good deal of support to the industry. But in reality, unfortunately, very few in the field know about these measures. Here are some numbers for you: about $80 \%$ of entrepreneurs know about the state support, but only $4 \%$ use it"1.

\section{Conclusions}

Intermediary roles by enabling connections between SMEs and external stakeholders (ie. academia, firms and institutions) could support their DX and adoption of I4.0 technologies. This intermediary role in Italy is largely covered by entrepreneurial associations, in the recognized function of DIHs.

Contrary, in the Russian Federation, the analysis shows that the measures and the efforts to support Russian SMEs are still insufficient in fostering a collaborative model for the adoption of digital technologies. To overcome these issues, OPORA could enhance networking activities for supporting the DX of the SMEs both at national and international level.

In fact, despite the State recognizing the crucial role of SMEs in the Russian economy and seeking to envision various instruments to support their development, Russian policy supporting SMEs is not stable, cohesive and systematic thus jeopardizing the effectiveness and efficiency of state SME support measures.

The study calls for further developments. First of all, the research calls for primary data as a basis to develop a more comprehensive study on the role of OPORA in comparison with that of the Italian business associations. Additionally, specific indicators should be defined to compare the effectiveness of intermediary roles with respect to the DX of SMEs.

The peculiar Russian case can be of interest for other studies and further investigation insofar as private SMEs have tried to undertake themselves, mainly supported by entrepreneurial associations, a digitalization process to some extent compensating or reacting to the unsatisfactory public support to SMEs. Russian SMEs appear to partially keep up with the 4.0 technological transformation through their private initiatives rather than public economic drives.

\footnotetext{
${ }^{1}$ SPIEF. New Investment Policy Mechanisms: Engines of Growth, Key conclusions. 2018. URL: https://roscongress.org/en/sessions/novye-mekhanizmy-investitsionnoy-politiki-lokomotivy-rosta/discussion/
} 


\section{References}

[1] Crupi A., Del Sarto N., Di Minin, A., Gregori G.L., Lepore D., Marinelli L., Spigarelli F. The digital transformation of SMEs - a new knowledge broker called the digital innovation hub // Journal of Knowledge Management. 2020. No. 24(6). P. 1263-1288.

[2] Benitez G.B., Ayala N.F., Frank A.G. Industry 4.0 innovation ecosystems: An evolutionary perspective on value co-creation // International Journal of Production Economics 2020. No. 228. P. 107-135.

[3] Chen Y. Integrated and Intelligent Manufacturing: Perspectives and Enablers // Engineering. 2017. No. 3(5). P. 588-595.

[4] Matt D.T., Rauch E. SME 4.0: The Role of Small- and Medium-Sized Enterprises in the Digital Transformation In: Matt D., Modrák V., Zsifkovits H. (eds) Industry 4.0 for SMEs. Cham: Palgrave Macmillan, 2020. P. 3-36.

[5] Camarinha-Matos L.M., Fornasiero R., Afsarmanesh H. Collaborative Networks as a Core Enabler of Industry 4.0. In: Collaboration in a Data-Rich World. PRO-VE 2017 // IFIP Advances in Information and Communication Technology. 2017. No. 506. P. 3-17.

[6] Matarazzo M., Penco L., Profumo L., Quaglia R. Digital transformation and customer value creation in Made in Italy SMEs: A dynamic capabilities perspective // Journal of Business Research. 2020. No.123. P. 642-656.

[7] Voronkova O.V., Kurochkina A.A., Firova I.P., Bikezina V.T. Current Trends in the Development of Small and Medium-Sized Enterprises and Individual Entrepreneurship in the Russian Federation // Revista Espacios. 2018. No. 39(41). P. 1-13.

[8] Dobrolyubova E., O. Alexandrov O., Yefremov A. Is Russia Ready for Digital Transformation? In: Alexandrov D., Boukhanovsky, A. Chugunov, Y. Kabanov, O. Koltsova (eds), Digital Transformation and Global Society. Cham: Springer, 2018.

[9] Komkov N.I. Scientific and technological development: Limitations and opportunities // Studies on Russian Economic Development. 2017. No. 28(1). P. 472-479.

[10] Shirokova G., Vega G., Sokolova L. Performance of Russian SMEs: exploration, exploitation and strategic entrepreneurship // Critical perspectives on international business. 2013.9 (1/2). P. 173-203

[11] Popkova E.G., Sergi, B.S. Will Industry 4.0 and Other Innovations Impact Russia's Development?", Sergi, B.S. // Exploring the Future of Russia's Economy and Markets, Emerald Publishing Limited. 2018. P. 51-68.

Доминик Лепоре, аспирант, ассистент преподавателя кафедры политологии, коммуникации и международных отношений, Университет Мачераты (Италия) (Италия, 62100, Мачерата, Виа Джованни Марио Крешимбени, 30/32). E-mail: d.lepore@studenti.unimc.it

Фабио Коаччи, аспирант, ассистент преподавателя кафедры политологии, коммуникации и международных отношений, Университет Мачераты (Италия) (Италия, 62100, Мачерата, Виа Джованни Марио Крешимбени, 30/32); аспирант, преподаватель, кафедра мировых политических процессов, факультет управления и политики, Московский государственный институт международных отношений МИД Российской Федерации (119454, Россия, г. Москва, пр. Вернадского, 76).

E-mail: f.coacci1@studenti.unimc.it.

\section{ПРЕДПРИНИМАТЕЛЬСКИЕ ПОСРЕДНИКИ, СПОСОБСТВУЮЩИЕ ЦИФРОВОЙ ТРАНСФОРМАЦИИ МСП: СРАВНИТЕЛЬНЫЙ АНАЛИЗ ИТАЛИИ И РОССИЙСКОЙ ФЕДЕРАЦИИ}

\section{Аннотация}

Статья направлена на исследование роли предпринимательских ассоциаций как посредников в поддержке цифровой трансформации малых и средних предприятий в Италии и Российской Федерации. Современное состояние анализируется с учетом уровня цифровизации МСП в обеих странах, а также деятельности и особенностей наиболее важных предпринимательских ассоциаций в их роли посредников между частным бизнесом и государственными деятелями. В статье используется сравнительный метод, основанный на итальянском и российском опыте: Конфиндустрия и Конфартиджанато в Италии рассматриваются в сравнении с Опорой в Российской Федерации. Результаты исследования демонстрируют высокие ожидания в отношении роли предпринимательских посредников в поддержке цифровой трансформации МСП. Соответственно, в статье определены направления дальнейшего развития их роли.

Ключевые слова: МСП, Италия, Российская Федерация, Индустрия 4.0, цифровизация, предпринимательские ассоциации, центры цифровых инноваций, «Опора России». 